\title{
VOCABULARY MASTERYAS A FACTOR THAT INFLUENCE ABILITY TO WRITE EXPOSITION TEXT
}

\author{
Trisna Helda, Rahayu Fitri \\ STKIP PGRI Sumatera Barat \\ Email : trisna_helda@yahoo.co.id
}

\begin{abstract}
The research is motivated by the following cases. First, students vocabulary deficiencies in writing so have difficulty in presenting ideas into a text. Second, the students do not understand about exposition text. Third, students difficult to differentiate exposition text with other text. Fourth, students difficult to develop ideas in writing, so that the resulting of their text is not in accordance with the idea that their think. Fifth, students difficult to write cohesion and coherence paragraphs. This type of this research is quantitative with correlation method. The population in this research is students of class X SMA Negeri $12 x 11$ Enam Lingkung Padang Pariaman District with 281 students. In this research, the sampling technique is proportional random sampling with 27 students. In this research, there are two variables, are independent variable and the dependent variable. The independent variables are vocabulary mastery $(X)$ and the dependent variable is the exposition text writing skills $(Y)$. Conclusions of this research are as follows. First, vocabulary mastery of class X SMA Negeri $12 x 11$ Enam Lingkung Padang Pariaman District with an average value of 73,17 which are in the category Lebih dari Cukup. Second, the writing skills exposition text of class X SMA Negeri $12 x 11$ Enam Lingkung Padang Pariaman District with an average value of 70,98 which are in the category Lebih dari Cukup. Third, there is a relationship between the vocabulary mastery with writing skill exposition text of class $X$ SMA Negeri $12 x 11$ Enam Lingkung Padang Pariaman District because $t_{\text {count }}>t_{\text {table. }}$. The conclusion of this research is the vocabulary mastery is a factors that influence significantly the writing ability exposition text of class X SMA Negeri $12 x 11$ Enam Lingkung Padang Pariaman District.
\end{abstract}

Keywords : vocabulary mastery, exposition text 


\section{INTRODUCTION}

Students should master the Indonesian language learning skills that includes four aspects, are listening skills, speaking, reading and writing. Writing is one language skills are very important and should be mastered by students, in addition to the three aspects of other skills. By writing skills, students can express their ideas, thoughts, feelings, and experiences to others. In addition to essential and must be mastered by all students, writing is also a complex skill, because it involves many aspects of language mastery. One aspect of language it is the mastery of vocabulary. Semi (2009), explain that generally there arefive goals writes as follows. (1) provides direction, (2) describe something, which provide a description or explanation of a thing that should be known by others, (3) tell the story, (4) summarizes, and (5) convince others to agree with him.

Vocabulary is a vocabulary word or set of words that are owned by a person or group of people from the same neighborhood, which when heard or read will cause a reaction for those who hear or read it. Chaer (2007) argues that the vocabulary is the word that is controlled by a person or group of people from the same neighborhood. Vocabulary is also one aspect of language that has an important role in the activities. The more vocabulary one has the easier one's ideas or his ideas in the form of written language. Exposition text is the translation of an idea on a regular basis on a topic that aims to inform the reader something. Through the exposition text, students can explain or describe nature of a thing that can add insight for readers and most importantly, this text does not affect the nature of the reader. In accordance with the opinion of Dalman (2014) which states that writing is a form of communication activities delivering messages (information) in writing to the other party by using the written language as a tool or medium. Writing is a creative process of expressing ideas in the form of written language with the aim, for example to say, persuade, or entertain. The results of the creative process is commonly referred to as an text or discourse.

In the Indonesian language learning, in senior high school, students are required of skill to write exposition text. It is listed in Kurikulum Tingkat Satuan Pendidikan (KTSP) class X in the 1 st half $4^{\text {th }}$ Standar Kompetensi "mengungkapkan informasi dalam berbagai bentuk paragraf (naratif, deskriptif, ekspositif)" and $4.3^{\mathrm{th}}$ Kompetensi Dasar "menulis gagasan secara logis dan sistematis dalam bentuk ragam paragraf ekspositif" (Depdiknas, 2006).

Based on observations and interviews conducted with Indonesian teacher of class X SMA Negeri 1 2x11 Enam Lingkung Padang Pariaman District with Mrs. Dra. Yarmi Umar, S.Pd., on February 20, 2016, obtained information that the exposition text writing skills of students class $\mathrm{X}$ SMAN $1 \quad 2 \times 11$ Enam Lingkung Padang Pariam

an District is still relatively low. Problems that are often experienced by students during the learning process, especially writing exposition text are as follows. First, students vocabulary deficiencies in writing so have difficulty in presenting ideas into a text. Second, the students do not understand about exposition text. Third, students difficult to differentiate exposition text with other text. Fourth, students difficult to develop ideas in writing, so that the resulting of their text is not in accordance with the idea that their think. Fifth, students difficult to write cohesion and coherence paragraphs.

Therefore, a factorthat influence the low ability of students writing exposition text ability is the lack of mastery of vocabulary. According to Tarigan (1993), the vocabulary is one part of the language that has an important role in the activities of writing, including writing exposition text. The quality of a person's language skills depending on the quantity and quality of its vocabulary. Increasingly rich vocabulary which is owned the greater the possibility for skilled 
language. According Atmazaki (2007), vocabulary deficiency can weaken a person said. Based on expert opinions above, it can be concluded that the vocabulary and writing ability of exposition text are intimately correlated. The higher a person's vocabulary mastery that he wrote the results will be even better. Based on the above problems, it needs to be conducted research to find out vocabulary mastery as a factorthat influence exposition text writing skills of class X SMA Negeri 1 2x11 Enam Lingkung Padang Pariaman District.

\section{METHODOLOGY}

The type of this research is quantitative by using the correlation method. The population in this research are students of class X SMA Negeri 1 2x11 Enam Lingkung Padang Pariaman District with 281 students. The sampling technique used in this research is proportional random sampling, sample of 27 students. In this research, the data collected by providing objective test of 60 questions to test vocabulary. Data were collected through several steps work as follows. First, the sample was given an answer sheet that contains the answer with A, B, C, D and E choices. Second, the sample responded by way of crossing one of the alternatives are considered the most correct answers within 60 minutes. Third, the students' answers were collected. Fourth, the students' answers were analyzed according to the indicators assessed, are synonyms, antonyms, and homonims. After that, do the data retrieval exposition essay writing skills of students by using tests of performance involves three steps as follows. First, students are assigned to write of exposition text with the theme that has been determined. Second, the task of the students was collected. Third, students' assignments were analyzed according to the indicators assessed. Data analysis techniques in the study was conducted by analyzing data obtained from the sample. According to Abdurrahman and Ellya Ratna (2003), the collected data, analyzed through nine stages. These stages are described as follows. First, write the score to measure vocabulary mastery and writing skills scores of exposition text. For vocabulary, a score of 1 was given for a correct answer and a score of 0 if the answer is wrong. To measure the exposition text writing skills assisted by using the indicator as follows. (1) providing information, understanding and knowledge to readers, (2) answering the question of what, who, why, when, and how, (3) delivered with style straightforward and using (mostly) raw language, and (4) served with neutral, impartial, and imposing views or attitude writers against readers. Second, changing the vocabulary test scores and scores of students ability to write the exposition text into value using the formula percentage. Third, determine the average value calculated. Fourth, convert the value of vocabulary mastery and writing skills exposition text to skala 10 table. Fifth, make a histogram vocabulary mastery and exposition text writing skills. Sixth, to test requirements analysis Seventh, correlate the value of vocabulary students with good grades exposition essay writing skills of students using the formula coefficient product moment correlation. Ninth, testing of the hypothesis. Tenth, to analyze, discuss, and summarize the results of data analysis.

\section{RESULTS AND DISCUSSION}

In his research, data consisted of two variables, are vocabulary mastsery and exposition text writing skills. Both figures are collected on May 21, 2016.

\section{Vocabulary Mastery}

In assessing students' mastery of vocabulary, indicators referring to the opinion of Tarigan (1993). First, synonyms. Second, antonyms. Third, homonyms. Collected of vocabulary mastery data by providing objective tests. The test is given in the form of multiple choice alternative answers A, B, C, D and E. The time given to students taking the test is 60 minutes. 
The students' answers were analyzed by measuring instrument ratings. Based on the research findings, it is known that the vocabulary of class X SMA Negeri $12 \times 11$ Enam Lingkung Padang Pariaman District in general is in qualifying Lebih dari Cukup (LdC) with an average value of 73,17 is at mastery level range of $66-75 \%$ in skala 10 . For a description of the data can be seen in the form of a score vocabulary mastery of class X SMA Negeri $12 \times 11$ Enam Lingkung Padang Pariaman District every indicator. Each element examined at intervals of 315. That is, the highest score obtained by the students is 15 and the lowest score is 3 . The findings can be detailed as follows.

Table 1. Acquisition Indicator Each Vocabulary Mastery Score of Class X SMAN $12 x 11$ Enam Lingkung Padang Pariaman District

\begin{tabular}{|c|c|c|c|c|}
\hline Number & Indicator & Score & \begin{tabular}{|c|} 
Number \\
of Student
\end{tabular} & Percentage \\
\hline \multirow[t]{6}{*}{1} & \multirow[t]{6}{*}{ Synonym } & 12 & 4 & $14,81 \%$ \\
\hline & & 11 & 9 & $33,34 \%$ \\
\hline & & 10 & 7 & $25,93 \%$ \\
\hline & & 9 & 4 & $14,81 \%$ \\
\hline & & 8 & 2 & $7,41 \%$ \\
\hline & & 3 & 1 & $3,70 \%$ \\
\hline \multirow[t]{7}{*}{2} & \multirow[t]{7}{*}{ Antonym } & 15 & 9 & $33,34 \%$ \\
\hline & & 14 & 5 & $18,52 \%$ \\
\hline & & 13 & 4 & $14,81 \%$ \\
\hline & & 12 & 5 & $18,52 \%$ \\
\hline & & 11 & 2 & $7,41 \%$ \\
\hline & & 9 & 1 & $3,70 \%$ \\
\hline & & 3 & 1 & $3,70 \%$ \\
\hline \multirow[t]{6}{*}{3} & \multirow[t]{6}{*}{ Homonym } & 11 & 12 & $44,45 \%$ \\
\hline & & 10 & 6 & $22,22 \%$ \\
\hline & & 9 & 5 & $18,52 \%$ \\
\hline & & 8 & 2 & $7,41 \%$ \\
\hline & & 7 & 1 & $3,70 \%$ \\
\hline & & 4 & 1 & $3,70 \%$ \\
\hline
\end{tabular}

According to the table above, can be described in three categories. These three categories are as follows. First, for synonyms (indicator 1) students who received a score of 12 amounted to 4 students $(14.81 \%)$, a score of 11 numbered $9(33.34 \%)$, a score of 10 numbered $7(25.93 \%)$, a score of 9 numbered $4(14.81 \%)$, a score of 8 numbered $2(7.41 \%)$, and a score of 3 numbered 1 person (3.70\%). Second, for antonyms (indicator 2) students who received a score of 15 numbered $9(33.34 \%)$, a score of 14 of 5 people (18.52\%), a score of 13 amounted to 4 people $(14.81 \%)$, a score of 12 numbered 5 (18.52\%), a score of 11 numbered $2(7.41 \%)$, a score of 9 numbered 1 person (3.70\%), and a score of 3 numbered 1 student (3.70\%). Third, for homonyms (indicator 3) who obtained a score of 11 amounted to 12 students (44.45\%), a score of 10 numbered $6(22.22 \%)$, score 9 of 5 people $(18.52 \%)$, a score of 8 totaling 2 people (7.41\%), a score of 7 numbered 1 person $(3.70 \%)$, and a score of 4 numbered 1 person $(3.70 \%)$.

Table 2. Frequency Distribution Mastery of Vocabulary Class X SMAN 1 2x11 Enam Lingkung Padang Pariaman District 


\begin{tabular}{|c|c|c|c|}
\hline Number & $\mathbf{X}$ & $\mathbf{F}$ & $\mathbf{F X}$ \\
\hline 1 & 84,44 & 4 & 337,76 \\
\hline 2 & 82,22 & 1 & 82,22 \\
\hline 3 & 77,78 & 3 & 233,34 \\
\hline 4 & 75,56 & 4 & 302,24 \\
\hline 5 & 73,33 & 7 & 513,31 \\
\hline 6 & 71,11 & 2 & 142,22 \\
\hline 7 & 68,89 & 4 & 275,56 \\
\hline 8 & 66,67 & 1 & 66,67 \\
\hline 9 & 22,22 & 1 & 22,22 \\
\hline \multicolumn{2}{|c|}{ Amount } & $\mathbf{2 7}$ & $\mathbf{1 9 7 5 , 5 4}$ \\
\hline
\end{tabular}

The average value calculated for the students' vocabulary mastery can be determined by using a formula of arithmetic mean (M). Based on these data, it can be concluded that the arithmetic mean (M) for the vocabulary of students in general are classified in qualifying 73.17 Lebih dari Cukup (LdC) is at mastery level ranged 66-75\%. After learning the arithmetic mean (M) for the students' vocabulary mastery of class X SMA Negeri $12 \times 11$ Enam Lingkung Padang Pariaman District were grouped into Skala 10. Grouping mastery of vacabulary of students can be seen in table following.

Table 3. Classification Vocabulary Mastery students of Class X SMAN 1 2x11 Enam Lingkung Padang Pariaman District

\begin{tabular}{|c|c|c|c|c|}
\hline Number & Level of Mastery & Qualification & Frequency & $\begin{array}{c}\text { Percentage } \\
(\boldsymbol{\%})\end{array}$ \\
\hline 1 & $96-100 \%$ & Sempurna & 0 & 00,00 \\
\hline 2 & $86-95 \%$ & Sangat baik & 0 & 00,00 \\
\hline 3 & $76-85 \%$ & Baik & 8 & 29,63 \\
\hline 4 & $66-75 \%$ & Lebih dari cukup & 18 & 66,67 \\
\hline 5 & $56-65 \%$ & Cukup & 0 & 00,00 \\
\hline 6 & $46-55 \%$ & Hampir cukup & 0 & 00,00 \\
\hline 7 & $36-45 \%$ & Kurang & 0 & 00,00 \\
\hline 8 & $26-35 \%$ & Sangat kurang & 0 & 00,00 \\
\hline 9 & $16-25 \%$ & Buruk & 1 & 3,70 \\
\hline 10 & $0-15 \%$ & Sangat buruk & 0 & 00,00 \\
\hline
\end{tabular}

Vocabulary mastery of class X SMA Negeri 1 2x11 Enam Lingkung Padang Pariaman District generally includes three categories. These three categories are as follows. First, the category of Baik (B) which is at the level of 76-85\% mastery. Second, the category Lebih dari Cukup (LdC) which is at the level of 66-75\% mastery. Third, the Buruk category (Br) which is at the level of $16-25 \%$ mastery. For the students' vocabulary mastery analyzed by three indicators. All three indicators are as follows. First, synonyms. Second, antonyms. Third, homonyms. Based on the analysis of the three indicators, it was concluded that the vocabulary was lowest for the indicator synonyms. This is evidenced by the average value of 67.16 which is the qualification of Lebih dari Cukup ( $\mathrm{LdC}$ ). Rate synonym indicator occurs when the student is able to understand a word equation. The equation of a word's meaning, not the words but the meaning is the same. Most indicators are indicators of student mastered antonym. This is evidenced by the vocabulary students are on the qualification Baik (B), with an average value of 81.71 . For this indicator, the students' answers will be corrected and given 
a score if students know the meaning of words that are the opposite. From these results, it can be concluded that the vocabulary of students seen from the indicators antonyms already meet minimum completeness criteria, is 75 .

\section{Exposition Text Writing Ability}

In assessing students' ability to write exposition text, indicators referring to the opinion of Semi (2009:51) that characteristic of exposition text. First, the form of writing that aims to provide information, insight and knowledge to the reader. Second, its answer questions about what, who, why, when, and how. Third, presented with a straightforward style and using (mostly) standard language. Fourth, presented in a neutral tone, impartially and impose outlook or attitude of the author towards the reader.

Collected data exposition text writing skills by providing test performance, is essay writing exposition with the theme "How to Maintain Environmental Hygiene". Rate to see the exposition essay writing skills in the analysis based on the indicators that have been determined. Description of data can be visualized in the form of exposition text writing skills scores class X SMA Negeri 1 2x11 Enam Lingkung Padang Pariaman District for each indicator. Each element examined using interval 1-3. That is, the highest score obtained by the students is 3 and the lowest score is 1 . The findings can be detailed as follows.

Table 4. Acquisition of Every Indicators Writing Exposition Score Class X SMAN 1 2x11 Enam Lingkung Padang Pariaman District

\begin{tabular}{|c|c|c|c|c|}
\hline Number & Indicator & Score & $\begin{array}{c}\text { Number } \\
\text { of Student }\end{array}$ & Percentage \\
\hline \multirow[t]{2}{*}{1} & \multirow{2}{*}{$\begin{array}{l}\text { Provide information, understanding, and } \\
\text { knowledge to the reader }\end{array}$} & 2 & 8 & $29,63 \%$ \\
\hline & & 1 & 19 & $70,37 \%$ \\
\hline \multirow[t]{2}{*}{2} & \multirow{2}{*}{$\begin{array}{l}\text { Answering the question of what, who, } \\
\text { why, when, and how }\end{array}$} & 3 & 8 & $29,63 \%$ \\
\hline & & 2 & 19 & $70,37 \%$ \\
\hline \multirow[t]{3}{*}{3} & \multirow{3}{*}{$\begin{array}{l}\text { Delivered with a straightforward style } \\
\text { and with (generally) language } \\
\text { standard }\end{array}$} & 3 & 15 & $55,56 \%$ \\
\hline & & 2 & 8 & $29,63 \%$ \\
\hline & & 1 & 4 & $14,81 \%$ \\
\hline \multirow[t]{3}{*}{4} & \multirow{3}{*}{$\begin{array}{l}\text { Served with a neutral, impartial } \\
\text { and not to impose the views or } \\
\text { the attitude of the author towards the reader }\end{array}$} & 3 & 16 & $59,26 \%$ \\
\hline & & 2 & 10 & $37,04 \%$ \\
\hline & & 1 & 1 & $3,70 \%$ \\
\hline
\end{tabular}

Based on the above table, the data can be described into four categories. These four categories are as follows. First, provide information, understanding, and knowledge (indicator 1) students who received a score of 2 , amounting to 8 people $(29.63 \%)$ and the score 1 totaled 19 students (70.37\%). Second, to answer the question of what, who, why, when, and how (indicator 2) students who received a score of 3 amounted to 8 students $(29.63 \%)$ and score 2 amounted to 19 students $(70.37 \%)$. Third, presented with a straightforward style and with (generally) standard language (indicators 3) students who received a score of 3 amounted to 15 students $(55.56 \%)$, a score of 2 , amounting to 8 people $(29.63 \%)$, and a score of 1 totaled 4 $(14.81 \%)$. Fourth, served with a neutral, impartial, and not to impose the views or attitude of the author towards the reader (indicator 4) students who received a score of 3 of 16 students $(59.26 \%)$, score 2 of 10 students (37.04\%), and score 1 numbered 1 student (3.70\%).

Table 5. Frequency Distribution Exposition Text Writing Skills Class X SMAN $12 x 11$ Enam Lingkung Padang Pariaman District

\begin{tabular}{|c|c|c|c|} 
Number & $\mathbf{X}$ & $\mathbf{F}$ & FX \\
\hline
\end{tabular}




\begin{tabular}{|c|c|c|c|}
\hline 1 & 83,33 & 6 & 499,98 \\
\hline 2 & 75 & 8 & 600 \\
\hline 3 & 66,67 & 8 & 533,36 \\
\hline 4 & 58,33 & 4 & 233,32 \\
\hline 5 & 50 & 1 & 50 \\
\hline \multicolumn{2}{|r|}{ Amount } & 27 & 1916,66 \\
\hline
\end{tabular}

The average value calculated for the students' vocabulary mastery can be determined by using a formula of arithmetic mean (M). Based on these data, it can be concluded that the arithmetic mean (M) for the mastery of writing skills students exposition text is 70,98 pertained to qualifications is Lebih dari Cukup ( $\mathrm{LdC}$ ) are in the 66-75\% level of mastery. After learning the arithmetic mean (M) for the exposition text writing skills of students, grades exposition text writing skills class X SMA Negeri 12 2x11 Enam Lingkung Padang Pariaman District were grouped into skala 10. Grouping exposition text writing skills of students can be seen in the following table. 
Table 6. Classification Essay Writing Skills Exposition Class X SMAN $12 x 11$ Enam Lingkung Padang Pariaman District

\begin{tabular}{|c|c|c|c|c|}
\hline Number & Level of Mastery & Qualification & Frequency & $\begin{array}{c}\text { Percentage } \\
(\%)\end{array}$ \\
\hline 1 & $96-100 \%$ & Sempurna & 0 & 00,00 \\
\hline 2 & $86-95 \%$ & Sangat baik & 0 & 00,00 \\
\hline 3 & $76-85 \%$ & Baik & 6 & 22,22 \\
\hline 4 & $66-75 \%$ & Lebih dari cukup & 16 & 29,63 \\
\hline 5 & $56-65 \%$ & Cukup & 4 & 44,45 \\
\hline 6 & $46-55 \%$ & Hampir cukup & 1 & 3,70 \\
\hline 7 & $36-45 \%$ & Kurang & 0 & 00,00 \\
\hline 8 & $26-35 \%$ & Sangat kurang & 0 & 00,00 \\
\hline 9 & $16-25 \%$ & Buruk & 0 & 00,00 \\
\hline 10 & $0-15 \%$ & Sangat buruk & 0 & 00,00 \\
\hline
\end{tabular}

According to the table above, obtained an idea of the exposition text writing skills class $\mathrm{X}$ SMA Negeri 1 2x11 Enam Lingkung Padang Pariaman District. This will be explained as follows. First, students who obtain the qualifying grades Baik (B) amounts to 6 students $(22.22 \%)$ are in the $76-85 \%$ level of mastery. Second, students who obtain the qualifying grades Lebih dari Cukup (LdC) of 16 students (29.62\%) are in the 66-75\% level of mastery. Third, students who obtain the qualifying grades with Cukup (C) amounting to 4 students $(44.44 \%)$ are in the 56-65\% level of mastery. Fourth, students who scored with a qualified Hampir Cukup (HC) numbered 1 student (3.70\%) are in the 46-55\% level of mastery.

There are sample exposition text got a score of 2 for the indicator to provide information, knowledge and understanding to the reader.

"Lingkungan"

Lingkungan adalah tempat sekumpulan makhluk hidup yang tinggal didalamnya. Lingkungan yang hijau bisamenghasilkan udara yang segar, yang bisa membuat kita tenang dan nyaman.

Faktor-faktor yang menyebabkan lingkungan menjadi kotor adalah karena ulah manusia yang seenang-wenang dan pabrik-pabrik yang membuang sisa limbah kesungaisehingga mencemari sungai yang membuat ikan mati.

Akibatnya lingkungan yang kotor adalah tersebar penyakit pada masyarakat seperti diare dan flu. Dan akibat pabrik yang tidak bertanggung jawab, ikan-ikan disungai pada mati.

Untuk menjaga lingkungan agar tetap bersih kita harus melakukan banyak penghijauan dan bertindak cepat agar pemerintah dapat memberikan sanksi pada pemilik pabri tsb.

From sample of students' writing exposition text above seen from the indicators provide information, knowledge and understanding gained a score of 2, because it provides insight and knowledge but do not provide information to the reader. As for the sentence that gives the sense, that the sentence on the line 1-2" lingkungan adalah tempat sekumpulan makhluk hidup 
yang tinggal didalamnya". The sentence said the sentence that gives the sense because the sentence contained in the characteristics of sentences that give sense. The characteristics of the sentence that gives the sense that, to unravel, revealing information and express limitations (meaning) of a term marked with the word "is" (KBBI Online).

Moreover, among the flowers, there is also a sentence that provides the knowledge, that the sentence on the line 2-4 "lingkungan yang hijau bisa menghasilkan udara yang segar, yang bisa membuat kita tenang dan nyaman". The sentence is said to be a sentence that gives knowledge because in the sentence are the characteristics of sentences that say a sentence that gives knowledge. The characteristics of a sentence that provides the knowledge that is, everything that is known with regard to things that never happened (KBBI Online).

There are sample exposition text got a score of 3 for indicators answer questions about what, who, when, and how.

\section{"Lingkunganku Kepribadianku"}

Lingkungan merupakan hal penting yang harus diperhatikan bagi setiap individu maupun kelompok. Lingkungan dapat mencerminkan kepribadian atau atak setiap orang. Tidak mungkin jika seseorang yang tinggal dilingkungan kotor berkepribadian bersih, begitu juga sebaliknya.

Lingkungan yang bersih bisa saja berubah menjadi kotor dikarenakan oleh beberapa faktor diantaranya: membuang sampah sembarangan dan jarang bersih-bersih. Banyak hal negatif yang dapat terjadi bila lingkungan disekitar kita tercemar. Membuat malas adalah salah satunya. Jika kita belajar dikelas dengan lingkungan yang kotor maka rasa ingin untuk belajarpun akan turun atau berkurang bahkan bisa saja hilang.

Menjaga lingkungan agar tetap bersih bukanlah hal yang sulit yang dapat kita lakukan saat ini. Kemajuan teknologi sangat membantu kita dalam menjadikan lingkungan sekitar agar tetapasri. Misalnya hanya dengan menggunakan alat penyedot debu,debu-debu yang ada akan langsung tersedot kedalamnya. Jadi, kita tak perlu lagi mengangkat barang-barang yang menghalangi kita pada saat bersih-bersih. Maka dari itu marilah kita semua menjaga lingkungan agar kita terhindar dari suatu negatif yang mungkin saja mengintai kita. Ingat kebersihan lingkungan mencerminkan siapa diri kita yang sebenarnya.

Sample number 20 seen from the indicators answer questions about what, who, why, when, and how to obtain a score of 3, due to answer questions about what, who, when and how. It said answering the question of what it explains about what causes the environment dirty and what impact, it is proved the sentence in paragraph 2 rows 1-3, which is "lingkungan yang bersih bisa saja berubah menjadi kotor dikarenakan oleh beberapa faktor, diantaranya: membuang sampah sembarangan dan jarang bersih-bersih". Furthermore, said answering the question of who as clear as to who should pay attention to the environment to stay clean, it is proved the sentence in paragraph 1 lines 1-2, that "the environment is an important thing that must be considered for each individual or group". Furthermore, said answering the question of when it explains about when is a concern for protecting the environment is not a difficult thing, it is proved the sentence in paragraph 3 lines 1-2, that "lingkungan merupakan hal penting yang harus diperhatikan bagi setiap individu maupun kelompok". Furthermore, said answering the 
question of how it explains how to control the environment to stay clean and avoid dirty air, it is proved the sentence in the paragraph lines $4-5$, that "misalnya hanya dengan menggunakan alat penyedot debu, debu-debu yang ada akan langsung tersedot kedalamnya". Based on the above, it can be concluded that the student is able to write the essay exposition by loading answers about what, who, when and how.

There is sample exposition text got a score of 3 to indicators delivered with style straightforward and with (generally) standard language.

Lingkungan merupakan tempat kita tinggal, beradaptasi dan hidup, baik di lingkungan sekolah, dirumah, dan dimana pun

kita berada. Oleh karena itu kita semua harus menjaga lingkungan sekitar kita gar terlihat bersih dan indah.

$\underline{\text { Faktor }}_{2}$ lingkungan tidak bersih, dikarenakan sebagian siswa atau masyarakat tidak memperhatikan lingkungan sekitarnya, seperti membuang sampah sembarangan dan tidakmemperhatikan lingkungan.

Jika lingkungan tidak bersih maka kita tidak nyaman dan penyakit akan menyebar dimanamana. Cara menjaga lingkungan agar terlihat bersih dan indah.

Membuang sampah pada tempatnya

Membagi sampah2 (organik dan nonorganik)

Membersihkan ruangan setiap minggu.

The sample students in the above views of the indicators presented in the style of straightforward and with (generally) standard language obtained a score of 3, because there is only one word that is not straightforward and the four words that are not raw. Told not straightforward because there are no more detailed explanation, it is proved the sentence in paragraph 2 rows 3-4, which is "tidak memperhatikan lingkungan". Given the description of how the actions are not paying attention to the environment. Furthermore, said not default because the text is a lot of words that do not correspond with the Ejaan Bahasa Indonesia (EBI) such as the merger between preposition with the word that describes the details of the place and the cutting words, it is proved to the words contained in paragraphs 1,2 and 3, is "dirumah, dimana pun, faktor2, dansampah2". Based on the above, it can be concluded that the exposition text of class X SMA Negeri 1 2x11 Enam Lingkung Padang Pariaman District. there is one sentence that is not straightforward and the four words that are not raw.

There are sample exposition text got a score of 2 for indicators presented neutrally, impartially and not to impose the views or attitudes of authors to readers.

\section{"Lingkungan Idaman"}

Lingkungan adalah dimana kita tinggal, untuk mendiami suatu daerah tersebut. Lingkungan haruslah tetap bersih, sehatdan yang terpenting lingkungan tersebut harus ada taman yang hijau, untuk menyejukkan mata kita biar refles saat memandang.

Lingkungan yang bersih dapat juga tercemari, kalau kita tidak pandai merawatnya, misalkan seperti lingkungan yang kotor, karna kurangnya kesadaran sebagian orang untuk membuang 
sampah pada tempatnya, lingkungan yang tidak sehat. Serta lingkungan yang gersang karna kurangnya kesadaran kita untuk merawat lingkungan tersebut.

Lingkungan yang kotor dapat disebabkan oleh beberapa faktor. Diantaranya seperti : membuang sampah sembarangan, tidak menjaga kebersihan tidak adanya tanaman hijau. Serta, tidak adanya saluran pembuangan zat kimia, pembuangan limbah pabrik yang sembarangan dan tidak adanya saluran untuk pembuangan air.

Ada banyak cara yang bisa kita lakukan, untuk menjaga lingkungan sekitar biar bisa tetap bersih, steril. Diantaranya, seperti: menjaga kebersihan, tidak membuang sampah sembarangan, terutama sampah plastik dan zat kimia lainnya yang sukar untuk hancur, dan menyediakan TPS, dan terpenting adanya saluran air yang bersih untuk kehidupan sehari-hari kita, biar kita bisa tetap sehat di lingkungan yang sehat, nyaman dan steril.

The students sample in the above views of the indicators presented in a neutral and, impartially and not to impose the view of the reader obtain a score of 2 , because there is one sentence that is coercive because it requires the reader to keep the environment clean. This is evidenced in the sentence contained in paragraph 1 lines 2-4, that "lingkungan haruslah tetap bersih, sehat dan yang terpenting lingkungan tersebut harus ada taman yang hijau, untuk menyejukkan mata kita biar refles saat memandang ". Based on the above, it can be concluded that in the exposition text of class X SMA Negeri 1 2x11 Enam Lingkung Padang District, there is one sentence that is coercive.

Furthermore, based on the hypothesis test obtained, it can be concluded that there is a significant factor affecting the vocabulary with exposition text writing skills of class X SMA Negeri 1 2x11 Enam Lingkung Padang Pariaman District. H1 is accepted at significance level of $95 \%$ and $d k=(n-2)$ for $t_{\text {count }}>t_{\text {table }}(2.45>1.71)$. That is, the quality of students' language in writing depending on the level of vocabulary you have, the higher the vocabulary possessed the greater good writing skills. This is evidenced by the data vocabulary mastery with an average value of 73,17 which is classified Lebih dari Cukup (LdC) are in the range of grades 66-75, and data exposition essay writing skills with an average value of 70,98 which is classified Lebih dari Cukup $(\mathrm{LdC})$ are in the range of grades $66-75 \%$.

\section{CONCLUSION}

Based on the description of the data, data analysis, and discussion of vocabulary mastery one of the factors that affect the ability to write text of exposition class X SMA Negeri $12 \times 11$ Enam Lingkung Padang Pariaman District can conclude three things. First, vocabulary mastery of class X SMA Negeri 1 2x11 Enam Lingkung Padang Pariaman District classified Lebih dari Cukup (LdC) with an average value of 73,17 is in the range of 66-75\%. Second, exposition text writing skills of class X SMA Negeri 1 2x11 Enam Lingkung Padang Pariaman District classified Lebih dari Cukup ( $\mathrm{LdC}$ ) with an average value of 70,98 is in the range of 66-75\%. Third, there are significant factors that affect the vocabulary mastery with exposition text writing skills of class X SMA Negeri 1 2x11 Enam Lingkung Padang Pariaman District because $t_{\text {count }}>t_{\text {table }}(2.45>1.71)$ with degrees of freedom $\mathrm{df}=(n-2)$ the significance level of $0,95 \%$ that is equal to 1,71 to 0,74 the difference in numbers. Based on the above data, it can be concluded that the mastery of vocabulary among the factors that affect significantly the ability to write the exposition text of class X SMA Negeri 12 x 11 Enam Lingkung Padang Pariaman District. 


\section{REFERENCES}

Arikunto, Suharsimi. 2002. Prosedur Penelitian Suatu Pendekatan Praktik.Jakarta: PT Rineka Cipta.

Atmazaki. 2007. Kiat-kiat Mengarang dan Menyunting. Padang: UNP Press.Chaer, Abdul. 2007. Leksikologi dan Leksikografi Indonesia.Jakarta: Rineka Cipta.

Dalman. 2014. Keterampilan Menulis. Jakarta: Rajawali Press.

Keraf, Gorys. 1995. Eksposisi Komposisi Lanjutan II. Jakarta: Gramedia.

Manaf, Ngusman Abdul. 2008. Semantik : Teori dan Terapannya dalam BahasaIndonesia. Padang: Sukabina.

Nurgiyantoro, Burhan. 2001. Penilaian dalam Pengajaran Bahasa dan SastraIndonesia. Yogyakarta: BPSE

Semi, M. Atar. 2009. Menulis Efektif. Padang: UNP Press.

Tarigan, Henry Guntur. 1993. Pengajaran Kosakata. Bandung: Aksara.

Tarigan, Henry Guntur. 2008. Menulis Sebagai Suatu Keterampilan Berbahasa. Bandung: Angkasa.

Pateda, Mansoer. 1995. Kosakata dan pengajarannya. Ende: Nusa Indah.

Sudjana. 2005. Metode Statistik. Bandung: Persit. 